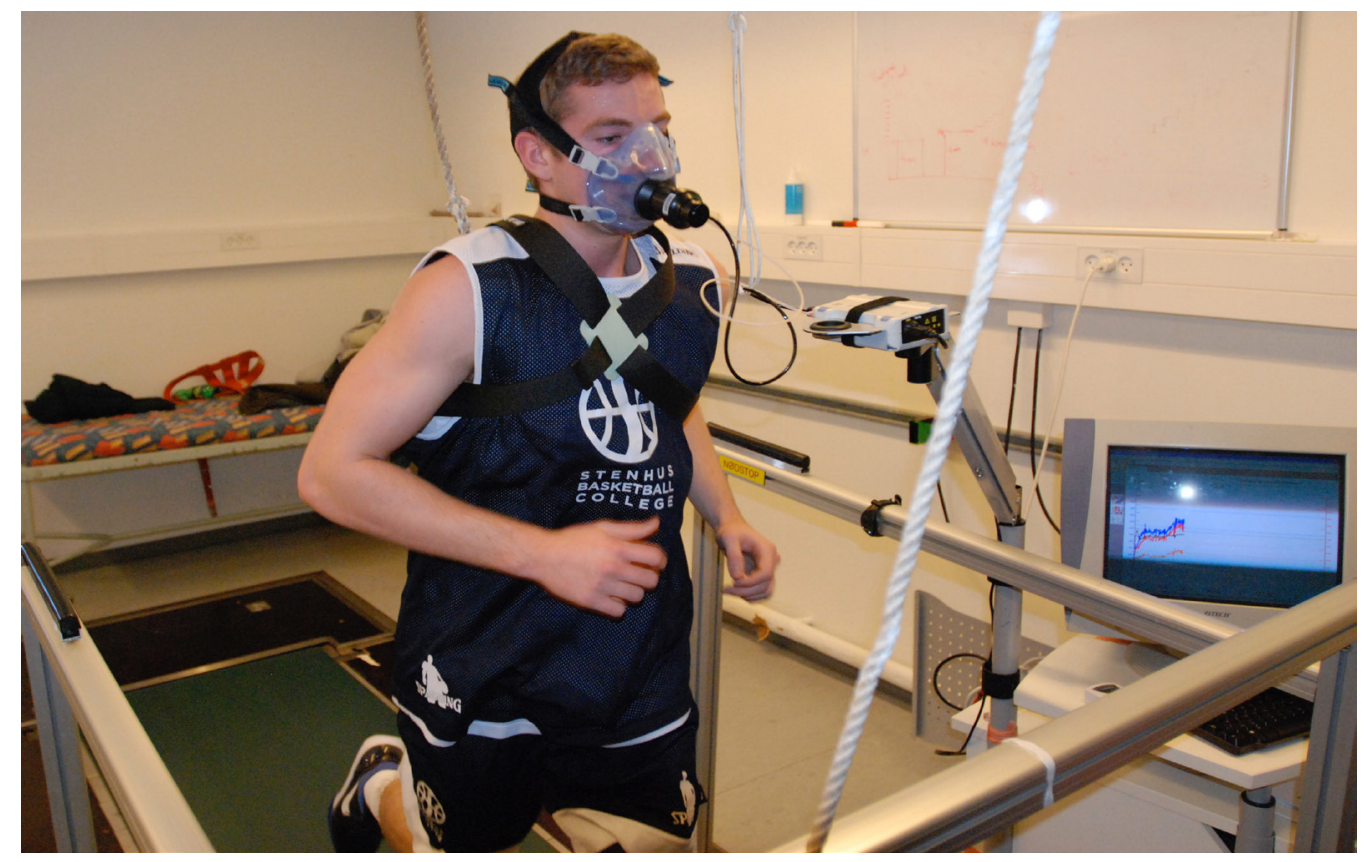

\title{
Talentudvikling
}

\section{Erfaringer fra et talentudviklingsmiljø med fokus på skolegang og sportslig udvikling}

\author{
JESPER SØRENSEN, JESPER HAUGE \& JACOB WIENECKE
}

50 timers ugentligt skolearbejde ${ }^{1}$, er hvad gymnasierne forventer af deres elever, når både den skemalagte undervisning og hjemmearbejdet regnes med. For mange unge elite-atleter kan denne arbejdsbelastning være svær at få til at gå op med en træningsuge, der ofte beslaglægger mere end 20 timer, når alle typer af træning tælles med. At mange af talenterne tilmed må transportere sig langt mellem hjem, skole og træning gør bare ondt værre, og de unge eliteudøvere stilles derfor ofte overfor valget: Skal jeg passe min skole eller min træning?

For at imødegå denne problematik etableredes for mere end tyve år siden Team Danmark-ordningen, der på udvalgte gymnasier, giver idrætstalentfulde gymnasielever mulighed for at strække uddannelsen over fire år i stedet for tre. Men er det ekstra år nødvendigt, eller kan det have utilsigtede konsekvenser for eleverne at forlænge skoletiden? Er der alternativer til den fireårige TD-ordning? Denne artikel beskriver oprettelsen og udviklingen af talentudviklingsmiljøet på Stenhus Gymnasium i Holbæk og belyser, hvordan spillerne på Stenhus Basketball College udvikler deres talent uden at gå på kompromis i deres valg af ungdomsuddannelse.

150 timer fremkommer som summen af 30 skemalagte undervisningstimer med ca. 20-30 minutters forberedelse til hver og elevernes skriftllige arbejde. 
JESPER SØRENSEN

Lektor og basketballtræner, Stenhus Gymnasium Underviser på Idrætsuddannelsen, Københavns Universitet js@stenhus-gym.dk

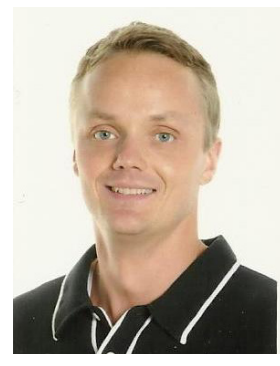

JESPER HAUGE

Lektor, Allerød Gymnasium

Underviser på Idrætsuddannelsen, Københavns Universitet

Tidligere Sportschef i DBBF

jesper.hauge@nexs.ku.dk

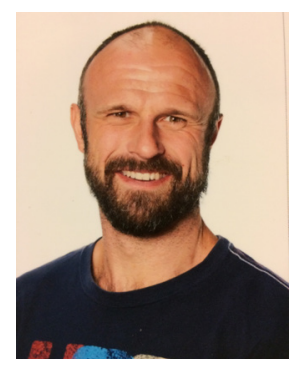

JACOB WIENECKE

Lektor ved Institut for Idræt og Ernæring, Københavns Universitet

wienecke@nexs.ku.dk

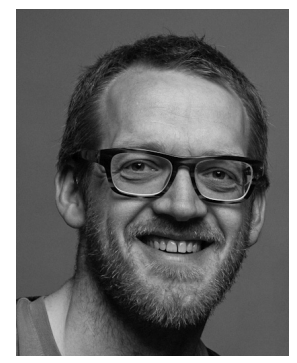

\section{ÅRSAGER TIL OPRETTELSE AF ET TALENTUDVIKLINGSMILJØ PÅ STENHUS GYMNASIUM \& HF}

Siden gymnasierne overgik til at være selvejende institutioner primært finansieret gennem elev-taxameter-ordningen, har kampen om eleverne været intens. Skolerne har de seneste år brugt mange ressourcer på at specialisere og brande sig overfor de unge, for derigennem at kunne fylde klasselokalerne med nye elever gerne med særlige kompetencer. Det er i denne kontekst, man skal se oprettelsen af Stenhus Basketball College på Stenhus Gymnasium og HF i 2010.

At skabe et godt talentudviklingsmiljø er en kompleks opgave, der kræver gode fysiske rammer, en stærk økonomi, og sidst men ikke mindst en arbejdsomhed, vedholdenhed og tålmodighed, der afspejler sig i en tro på projektet og dets evne til at tiltrække talenter. På Stenhus har man i hele processen lænet sig op ad den eksisterende danske forskning på området, og talentudviklingsmiljøet er på mange måder formet og udviklet med eksempelvis Kristoffer Henriksens resultater og guidelines i baghovedet (Henriksen, 2011). I 2013 udgav Team Danmark "Talent- 
huset", og tankerne og anbefalingerne i dette dokument har ligeledes tjent som rettesnor i udviklingen af talentmiljøet på Stenhus (Team Danmark, 2013).

På Stenhus er de fysiske rammer tæt på ideelle. Med tre moderne haller, et nyetableret styrketræningscenter og et avanceret fysiologisk testcenter er skolens sportsfaciliteter fremragende, og da gymnasiet ligger klods op ad Stenhus Kostskole, hvor talenterne bor og spiser, er transport-trekanten mellem hjem, skole og træning minimal. Spillerne har tæt på ubegrænset adgang til hal og styrketræning, hvilket giver størst mulig fleksibilitet, når de skal passe deres individuelle basketballtræning og styrketræning. I forbindelse med sportscollege-træningen, har eleverne adgang til en idrætsfysioterapeut med arbejdsplads på skolen, sådan at eventuelle skader kan behandles hurtigt og optimalt. Særlig komplicerede skader tilses af idrætslæge, Tommy Øhlenschlæger fra idrætsklinikken på Bispebjerg Hospital. Heldigvis har antallet af alvorlige skader på Stenhus Basketball College været meget lavt. Dette skyldes naturligvis en vis portion held, men også den forebyggende indsats, der ydes i løbet af spillernes tid på Stenhus. Alle elever gennemgår en fysioterapeutisk screening ved ankomsten til sports college, og hver eneste fredag er morgentræningen afsat til skadesforebyggende træning med fokus på balance, bevægelighed og funktionel styrke (se ugeskema nedenfor).

Økonomien på Stenhus Gymnasium \& HF er stærk. Skolen har længe været populær, og de mange taxametermidler, som det høje elevtal har bragt til skolen, har skolen forvaltet fornuftigt. At starte et sportscollege skal som nævnt ses som en investering i skolens brand og dens fremtidige popularitet og som en måde at tiltrække en særlig type elever. Man har fra ledelsens side ønsket eliteidrætsfolk blandt sine elever ud fra en antagelse om, at disse ville fremstå som stræbsomme og strukturerede rollemodeller for resten af skolens elever og tilmed være med til at understøtte skolens ønske om en markant sundhedsprofil.

Ud over at investere i de føromtalte idrætsfaciliteter har skolen også besluttet at bruge en del af sine lønkroner på at ansætte dygtige og anerkendte trænere til eleverne på sportscollege. Trænerne på Stenhus Sports College er desuden undervisningskompetente i gymnasiet og varetager udover collegetræningen også almindelig gymnasieundervisning. På Stenhus er trænergerningen sidestillet med undervisningen i de sædvanlige fag, hvilket har gjort løn- og arbejdsvilkår interessante for trænerne. Man er på denne måde lykkedes med at ansætte markante profiler som trænere i alle sportsgrene. At trænerne også er lærere på gymnasiet understøtter helhedstanken, og smidiggør samarbejdet mellem skole og sport.

Med den nye gymnasiereform anno 2016 presses landets ungdomsuddannelser på økonomien. Navnlig udbydere af den traditionelle studentereksamen STX har måttet finde sig i markante økonomiske stramninger. På Stenhus har det således været nødvendigt at tænke alternativt for at opretholde den høje kvalitet på sports college. Fra 2016 har man intensiveret arbejdet med at indgå sponsor- og samar- 
bejdsaftaler med lokale institutioner og erhvervsdrivende. Stenhus har flere gange modtaget legater fra Holbæk Kommunes Talentpulje, og med oprettelsen af et erhvervsnetværk forventer man, at kunne hente økonomisk opbakning samtidig med, at man forankrer sportscollege stærkere i byen. Det er ambitionen, at stedet skal komme styrket og mere strømlinet ud af denne udfordrende situation.

Da Stenhus Sports College så dagens lys i 2010, ansatte man to trænere og optog seks lokale basketballdrenge fra Holbæk. Seks år senere er talentudviklingsmiljøet vokset til også at omfatte badminton, fodbold, håndbold og tennis, og således er der i dag mere end $75^{2}$ talentfulde unge idrætsudøvere og 17 trænere på Stenhus Sports College. Denne artikel vil zoome ind på basketballmiljøet på Stenhus og beskrive den store udvikling dette har gennemgået i løbet af de seneste seks sæsoner. Som et konkret eksempel på stedets løfteevne præsenteres data fra fysiske test gennemført med stenhuseleverne i årene fra 2011-2015 sammenholdt med data fra de jævnaldrende ungdomslandshold anno 2010.

I Danmark er pigebasketball udfordret af et lavt antal af medlemmer på landsplan, og dette smitter i høj grad af på muligheden for rekruttering af piger til Stenhus. At piger samtidig synes sværere at flytte ud af deres vante rammer end drenge, gør rekrutteringen endnu mere kompliceret. Skoleåret 2016-2017 er anden sæson med pigebasketball på Stenhus, og er derfor ikke nær så langt i sin udvikling som drengeafdelingen. Da formålet med denne artikel er at beskrive erfaringer og resultater opnået i forbindelse med udviklingen af et talentudviklingsmiljø over tid, vil den hovedsagligt omhandle drengene.

\section{STENHUS BASKETBALL COLLEGE - TALENTUDVIKLING MED INDI- VIDUELT FOKUS}

I 2016 tæller Stenhus Basketball College 15 drenge og 10 piger fra hele landet, og havde man ikke insisteret på at opretholde den sportslige kvalitet for hver enkelt spiller, kunne man sagtens have optaget flere drenge - og derved øget gymnasiets taxameterindtægt. Når Stenhus i gennemsnit kun optager fem drengespillere om året, er det for at sikre, at de optagne spillere har et anseeligt basketballtalent, og at de er robuste nok til at klare de tre intense år med markant mere træning og skolegang, end de er vant til. Derudover er det vigtigt for produktets kvalitet, at hver enkelt spiller får tilstrækkelig opmærksomhed fra trænerne og spilletid nok i kampene. Ved kun at tilføje fem nye spillere om året opnår man desuden en gunstig alderssammensætning af holdet, der bevirker, at spillerne i løbet af de tre år både vil blive udfordret opad og nedad i forhold til deres fysiske og sportslige niveau, hvilket fremmer præstationsniveauet (d'Arripe-Loungueville et al. 2002). I alle træninger på Stenhus Basketball College oplever spillerne altså enten en for-

2 Heraf ca. $20 \%$ fra andre kommuner end Holbæk. 
nemmelse af at måtte stræbe efter de ældre og bedre spillere eller en fornemmelse af at mestre nye sider af spillet overfor jævnaldrende eller yngre spillere.

Selvom Stenhus har fokuseret på de to nuværende hold har det i de seneste år været stedets ambition at udvide drengeafdelingen til to U19-hold og samtidig forsøge at skabe et samarbejde med en klub, hvis herrehold spiller i landets næstbedste seniorrække. En udvidelse til to U19-hold ville give endnu bedre betingelser for at matche og udfordre spillerne på forskellige niveauer i løbet af en træningsuge og med tilføjelsen af et hold placeret i en lavere rangerende U19-række, ville det endvidere blive nemmere for de yngste spillere at få kvalitetsminutter på banen i kamp. På Stenhus Basketball College forventer man desuden, at opstarten af endnu et hold, vil åbne muligheden for at optage spillere, hvis talent kræver længere tid at udfolde, end man før har været villig til at acceptere. Når man indtil nu ikke har villet optage alt for uslebne diamanter, har årsagen som oftest været, at man ikke har kunnet garantere spilleren en træning, der matcher dennes niveau, og heller ikke har kunnet se, hvordan spilleren skulle kunne tilspille sig tilstrækkeligt med minutter i kampene i U19-ligaen. Tiden på banen under kamp er en afgørende faktor i udviklingen af de unge nystartede spillere. Med bedre tid til at udvikle relativt nystartede spillere med et eksempelvis usædvanligt godt fysisk talent, regner man med at kunne indfange en større del af landets talentmasse, hvilket både ville

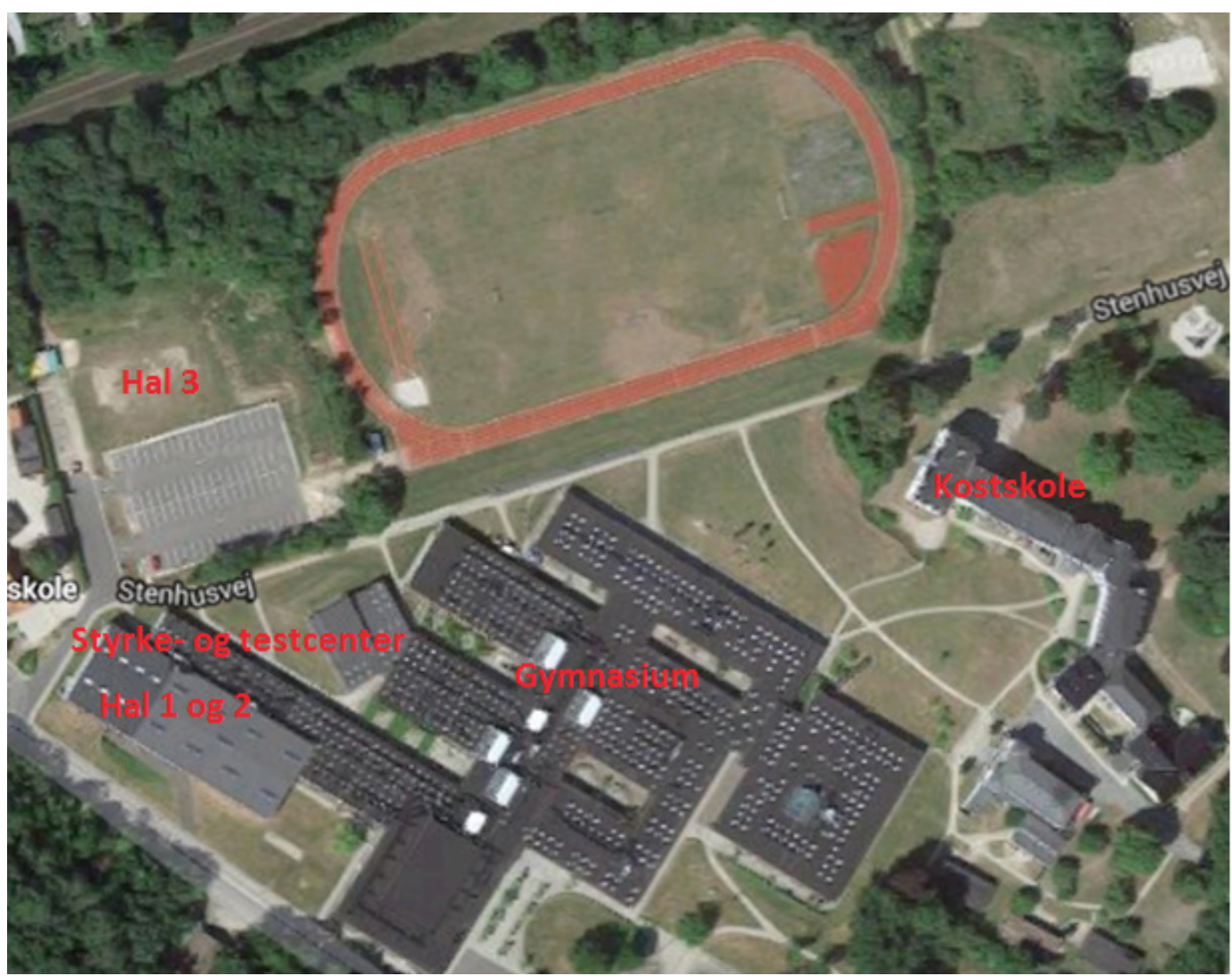


gavne Stenhus og basketballsporten i et bredere perspektiv. Når man på Stenhus ønsker et samarbejde med en 1. divisionsklub, er det for at kunne blive ved med at udfordre de bedste af tredjeårsspillerne og lette den svære overgang fra ungdomstil seniorbasketball.

Skal udvidelsen blive en succes, er det essentielt, at normeringen ikke forringes, sådan at alle spillere fortsat får den samme engagerede træning og personlige opmærksomhed fra trænerne som før. Det opfattes også som meget vigtigt, at der er sammenhæng og kontinuitet i træningsmetoderne og spilfilosofierne på Stenhus og i 1.divisionsklubben. At ansætte en træner, der er tilknyttet både Stenhus og 1.divisionsklubben fremstår som en forudsætning for udvidelsens succes.

\section{Dagligdagen på Stenhus Basketball College}

På Stenhus vægtes uddannelsen højt. Eleverne kan derfor frit vælge mellem gymnasiets mange studieretninger, så de får lige præcis den ungdomsuddannelse, de ønsker. Sportscollegeeleverne er altså ikke begrænsede af at skulle gå i "sportsklassen” for at kunne følge talentudviklingsprogrammet. For at sikre sig at elevernes skolegang forløber planmæssigt, er der fra ledelsen bevilliget løntimer til specifik studievejledning af sportseleverne. Her kan talenterne søge hjælp og vejledning, men det er også her, de bliver gået efter i fraværskortene, for på Stenhus håndhæves en regel om, at man ikke får lov at træne, hvis fraværet er for højt. Stenhus Gymnasium har siden 2015 været godkendt som Team Danmark uddannelsespartner, og derfor kan særligt talentfulde sportscollegeelever søge om TD-godkendelse og derefter om at strække deres uddannelse over et ekstra år. Som antydet ovenfor, er dette ikke noget Stenhus Sports College anbefaler, medmindre der er tungtvejende sportslige eller faglige årsager, der taler for det. En Team Danmark-vejleder er ansat for at sikre, at skole og idræt går op i en højere enhed for de (i 2016) 25 Team Danmark-godkendte elever på Stenhus.

Det har aldrig været en ambition, at Stenhus Sports College udelukkende skulle være et sted for den boglige elite, men altid været en forudsætning for stedets eksistens, at spillernes sportslige udvikling blev optimeret i samspillet med den boglige. Tanken om helhed i den personlige udvikling har været styrende for arbejdet på Stenhus, og for langt størstedelen af de elever, der har gennemført deres uddannelsestid på Stenhus, kan man sige, at den uddannelse, de har fået, har været så god som overhovedet mulig. Ingen elever har gennemført programmet på Stenhus uden at komme derfra med en studentereksamen, og for en del af dem var engagementet i basketballprogrammet sandsynligvis det, der motiverede dem til at gennemføre deres ungdomsuddannelse og opnå et brugbart resultat.

På Stenhus Gymnasium og HF ligger al undervisning mellem 8.15 og 14.55. Derfor er træningerne placeret umiddelbart før eller umiddelbart efter skoledagen. Dette kan lade sig gøre, fordi der praktisk talt ingen transporttid er mellem skole, 
hjem og træning, og fordi kostskolens måltider bliver serveret til tider afstemt med basketball-timeplanen. Eleverne oplever selvfølgelig, at de har travlt, men de er ikke stressede over at skulle få deres tid til at slå til på egen hånd. En af spillerne udtrykte det således: "Så længe vi holder os til planen, og udnytter tiden til det, den skal bruges til f.eks. afslapning, så går alting af sig selv.”

\begin{tabular}{|c|c|c|c|c|c|c|c|}
\hline Tid & Mandag & Tirsdag & Onsdag & Torsdag & Fredag & Lørdag & Søndag \\
\hline $7.00-8.00$ & $\begin{array}{c}\text { Basketball } \\
\text { Morgentræning } \\
\text { Individuel teknik }\end{array}$ & & & & $\begin{array}{l}\text { Skades- } \\
\text { forebyggende } \\
\text { morgentræning }\end{array}$ & & \\
\hline $8.15-14.55$ & Skole & Skole & Skole & Skole & Skole & & \\
\hline $15.00-17.00$ & $\begin{array}{l}\text { Basketball } \\
\text { Holdtræning }\end{array}$ & $\begin{array}{l}\text { Basketball } \\
\text { Holdtræning }\end{array}$ & $\begin{array}{c}\text { Basketball } \\
\text { Individuel } \\
\text { teknik }\end{array}$ & $\begin{array}{l}\text { Basketball } \\
\text { Holdtræning }\end{array}$ & $\begin{array}{c}\text { Basketball } \\
\text { Individuel teknik }\end{array}$ & & $\begin{array}{l}\text { Basketball } \\
\text { Holdtræning/ } \\
\text { Kampe }\end{array}$ \\
\hline $19.00-21.00$ & & Styrketræning & & & Styrketræning & & Styrketræning \\
\hline
\end{tabular}

Fig.1 Typisk ugeskema for basketballelev på Stenhus.

\section{Basketballtræning på Stenhus Basketball College: Udvælgelsen, udvik- lingen og træningsfilosofien}

Basketball er et holdspil, der stiller store krav til spillernes fysik, teknik og taktiske forståelse. På højeste plan er spillerne temmelig positionsspecialiserede med skarpt definerede spidskompetencer, om end der er en tendens til, at spillere, der behersker flere af spillets facetter, vinder større og større indpas på den internationale scene.

Når spillerne kommer til Stenhus i femtenårsalderen, er det de færreste, der er skarpt definerede som basketballspillere og endnu færre, der er fysisk parat til at træne på eliteniveau. I udvælgelsen lægges derfor stor vægt på spillerens totale potentiale - altså en vurdering af, hvor god spilleren kan blive som færdigudviklet basketballspiller. I denne vurdering indgår en sum af spillerens fysiske, tekniske og taktiske talent samt spillerens trænerbarhed og vedholdenhed. ${ }^{3}$ Vurderingen foretages på baggrund af en træningsweekend, en motiveret ansøgning og en samtale mellem trænere, spiller og forældre. At spilleren også skal overbevise trænere og ledere om, at han kan klare at tage en studentereksamen ved siden af, at han dyrker sin sport, er en præmis, der ligger i stedets værdigrundlag, og som ikke omgås.

Hvilken position spillerne spiller ved ankomsten til Stenhus, tillægges ikke den store vægt, når et nyt kuld skal udvælges. Det er stedets holdning, at man optager de største talenter i ansøgerfeltet, uanset om man derved må give køb på, at sammensætte et hold, der er ligeligt besat på alle fem positioner. Stenhus Basketball College opfatter sig selv som en basketball-uddannelsesinstitution i højere grad

3 Se Eibergs faktorer i Aldersrelateret træning (2007), Team Danmark. 
end et hold, der forsøger at optimere sine chancer for at vinde. Ikke dermed sagt, at man ikke spiller kampene for at vinde dem, men de skal ikke vindes for enhver pris - specielt ikke hvis prisen er en forspildt chance for talentudvikling. Mange ungdomstrænere føler sig tit stillet over for valget mellem at udvikle spillerne eller at vinde kampene. På Stenhus lyder parolen "Vi vil gerne udvikle vindere" - og med den i tankerne bedrives individuelt fokuseret talentudvikling med henblik på at skabe kompetente holdspillere, der i fremtiden kan indgå på et hvilket som helst voksenhold inden for evnernes rækkevidde, fordi de er fysisk, teknisk og taktisk veluddannede.

For at sikre spillernes kompatibilitet med ethvert spilkoncept de måtte møde efter deres tid på Stenhus, lægges vægten i træningen på de elementære tekniske og taktiske dele af basketballspillet. Man kunne givetvis opnå en række resultatmæssige "quick-fix-effekter" ved at lade spillerne udnytte deres medbragte spidskompetencer i stramt opsatte spilsystemer, men en sådan tilgang ville begrænse spillerne til ensidede funktionærer, hvis fremtidige evne til at agere i andre spilkoncepter formentlig ikke ville blive udfoldet helt. Spillere, der har trænet på denne ensidige måde, vil nemlig ofte komme både teknisk og taktisk til kort første gang, de bliver bedt om at deltage i et spilsystem, de ikke har prøvet før. I stedet for at terpe spilsystemer, trænes spillets elementære bestanddele og stenhusholdets spillestil er sammensat ud fra et ønske om at bringe alle elementerne i spil og altså ikke ud fra hvilke af dem, holdet behersker bedst. Dette betyder ikke, at Stenhus spiller procesorienteret basketball, hvor alle spilsystemer spilles lige meget, men at der i holdets angrebsarsenal ligger skyts til at udnytte alle de åbninger, som et modstanderholds forsvar kunne tænkes at give. At det naturligvis tager lang tid, før holdet kan forstå at anvende skytset rigtigt, koster helt sikkert holdet sejre i starten af hver sæson, men den pris er man villig til at betale i talentudviklingens navn.

Det ville ikke være retvisende at bruge slutplaceringer i U19-ligaen som målestok for udviklingen af spillerne på Stenhus. Dertil har alderssammensætningen af stenhusholdet, talentmassen på Stenhus og på landsplan i de forskellige årgange og dermed styrken af ligaen varieret for meget fra år til år. I stedet ønsker Stenhus at evaluere sig selv på, hvor meget de flytter de spillere, de tager ind, velvidende, at det er vanskeligt helt objektivt at kvantificere, hvor god en spiller er ved optag, og hvor meget bedre han er blevet i løbet af de tre år. Eksempelvis skyldes en del af denne udvikling ren og skær biologisk modning, der også ville have fundet sted i et andet miljø. I fraværet af et direkte mål for en spillers udvikling, benyttes spillerens opnåede meritter efter tiden på Stenhus som en slags indirekte mål for talentmiljøets løfteevne. På Stenhus fokuserer man på de spillere, der har opnået U-landskampe for første gang som Stenhusspiller, på de spillere, der er blevet sendt videre til klubber i landets bedste seniorrække og ikke mindst på de spillere, der i dag spiller på college i USA. Når man fremhæver disse succeshistorier som et 
mål for talentmiljøets kvalitet, hænger det blandt andet sammen med, at det endnu ikke er lykkedes for Stenhus at blive det sted, som landets største 15-17-årige talenter vælger at tage til. Stenhus optag er indtil nu kommet fra sub-eliten i en årgang og ofte fra mindre klubber uden et egentligt elitemiljø. At fortælle om de spillere, der opnåede landskampe og/eller et USA-ophold i forlængelse af deres tid på Stenhus, har vist sig at have stor effekt, når nye spillere skal rekrutteres til programmet. I 2014 konkluderede et projekt fra Københavns Universitet, at Stenhus Basketball Colleges størstes udviklingspotentiale ligger i fremover at kunne rekruttere spillere blandt de absolut største talenter i Danmark.

At få de bedste spillere i landet til Stenhus, ville hæve det sportslige niveau til gavn for alle i miljøet, idet spillere på alle niveauer har gavn af at træne med de bedste (d'Arripe-Loungueville et al. 2002). I Stenhus første leveår var det en stor opgave at lokke spillere til et nyopstartet projekt uden meritter og historie, og det har med tiden vist sig, at unge spillere i høj grad vælger miljø efter, de resultater tidligere årgange i miljøet har opnået - både individuelt og som hold. En af de helt store effekter ved at kunne tiltrække spillere fra øverste hylde ville derfor være at rekrutteringsarbejdet formentlig ville kunne lettes betydeligt på baggrund af holdets bedre resultater samt det øgede antal af spillere på U-landsholdene og som opnår ophold på college i USA. Rekrutteringen har været og er fortsat en meget stor del af arbejdet på Stenhus Sports College og en lettelse af denne opgave ville frigive tid til at optimere andre områder i miljøet.

Det er dog ikke helt entydigt, at det ville være optimalt for miljøet at samle størstedelen af landets ypperste talenter på Stenhus. Dette ville eksempelvis skabe udfordringer i forhold til at give alle spillere den nødvendige spilletid i kampene og desuden sænke antallet af kampe med kvalificeret modstand, da klubbernes U19hold ville dale i kvalitet med tabet af deres bedste spillere. Som en forholdsvis ny aktør på ungdomsbasketball-scenen er Stenhus desuden meget afhængig af at bevare en god relation til klubberne, som, når alt kommer til alt, har udviklet deres spillere fra børn til unge talenter. Det er klart, at klubberne gerne vil have et afkast af denne investering i form af seniorspillere af egen avl på deres førstehold og en manglende udsigt til dette ville formentlig resultere $i$, at klubberne ville modarbejde at sende spillere på talentskole. Heldigvis er der efterhånden en række gode talentmiljøer i dansk basketball, hvorfor den beskrevne høje koncentration af elitespillere på Stenhus vurderes hverken til at være eller blive realistisk.

\section{Den fysiske træning på Stenhus Basketball College}

Den fysiske træning varetages på Stenhus af universitetsuddannede trænere, der på sportscollege udelukkende arbejder med den fysiske del af spillernes udvikling. Styrketræningen har for førsteårs-eleverne primært et teknisk fokus, men udvikles over de tre år til slutteligt at bestå af tung og funktionel træning med plyome- 
triske elementer. Spillerne styrketestes en gang om måneden i forbindelse med den almindelige styrketræning med henblik på at justere belastningen så godt som muligt. For også i den daglige træning at kunne monitorere og dosere spillernes belastning bedst muligt bærer spillerne ofte online pulsbælter, så trænerne kan følge deres hjertefrekvens undervejs i boldtræningen og derigennem sikre, at der trænes med den rette intensitet.

I modsætning til vanskelighederne med at måle den tekniske og taktiske udvikling af en basketballspiller er det relativt enkelt at måle og evaluere den fysiske udvikling af en atlet. I hvert fald når man har løst opgaven, der består i at udvælge relevante, valide og gerne spilnære tests, der kan reproduceres med passende mellemrum over de tre år spilleren er på Stenhus. De aerobe, anaerobe og antropometriske mål indsamles fem gange årligt. Fire af gangene fastlægges konditallet med en YoYo IR2 test, mens den femte måling foretages direkte ved spirometri. Den anaerobe effekt og kapacitet testes i en Wingate-cykeltest, mens en fotocellestyret sprinttest over tyve meter og en såkaldt bounce-test hhv. måler spillernes accelerationsevne og evne til at udføre tre gentagne, maksimale, tobens afsæt. Ved hver af de fem årlige testseancer måles spillernes højde, vægt og kropssammensætning - sidstnævnte via bioimpedans.

At gennemføre det beskrevne testbatteri hyppigt og indenfor en tålelig tidsramme er blevet muliggjort efter, at Stenhus Gymnasium åbnede sit eget moderne test- og videnscenter i 2015. Man forventer sig meget af de kommende års dataopsamling og analyser, og regner med yderligere at kunne optimere den træningsfysiologiske del på Stenhus. Derudover ser man også med stor interesse på det udviklingspotentiale, der ligger i at teste og træne i den neurofysiologiske og neuropsykologiske kontekst. Her tænkes eksempelvis på tilvænning og indlæring af motoriske evner, spilintelligens samt opmærksomhed og multitasking.

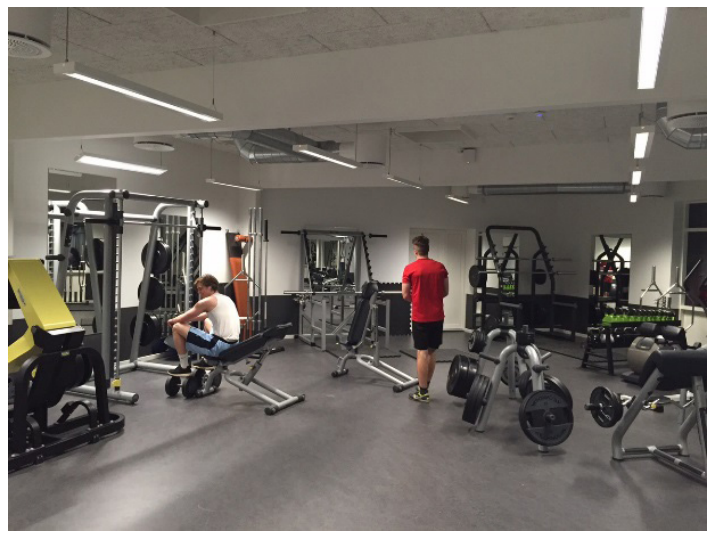




\section{Resultater af den fysiske træning frem til 2015}

Arbejdet med at følge spillernes fysiske udvikling via tests påbegyndtes allerede $\mathrm{i}$ 2010, da den første drengeårgang startede på Stenhus Basketball College. Dengang besluttede Stenhus trænere sammen med basketballforbundets sportschef, at udbyttet af den fysiske træning på Stenhus, skulle holdes op imod den fysiske formåen hos landets ungdomslandsholdspillere. Derfor blev U16 og U20-landsholdets spillere testet under DBBF-sportschefens ledelse i samarbejde med eksperter fra Københavns Universitet. At det netop blev U16 og U2o landsholdene, man udvalgte som målestok skyldtes, at deres alderssammensætninger naturligt nok giver det bedste sammenligningsgrundlag for hhv. en førsteårs og en tredjeårs stenhuselev.

I 2010 gennemførtes en standardiseret YoYo-IR1 test, en maximal iltoptagelsestest på løbebånd, en 30 sekunders Wingate cykeltest samt højde- og vægtmålinger for landsholdene og stenhusspillerne. Stenhusspillerne testedes igen i årene fra 2011-2015 på Københavns Universitet, men det var desværre ikke muligt at lave opfølgende tests på ungdomslandsholdsspillerne. Resultaterne af testene kan ses i tabellen nedenfor.

\begin{tabular}{|c|c|c|c|c|c|c|c|c|c|c|}
\hline & Spillere & Højde & Vægt & $\begin{array}{l}\text { YoYo } \\
\text { IR1 }\end{array}$ & $\begin{array}{l}\text { Maksimal } \\
\text { iltoptagelse }\end{array}$ & Kondital & $\begin{array}{c}\text { Anaerob } \\
\text { Effekt }\end{array}$ & $\begin{array}{l}\text { Anaerob } \\
\text { Kapacitet }\end{array}$ & $\begin{array}{l}\text { Anaerob } \\
\text { Effekt }\end{array}$ & $\begin{array}{l}\text { Anaerob } \\
\text { Kapacitet }\end{array}$ \\
\hline & antal & $\mathrm{cm}$ & $\mathrm{kg}$ & meter & $\begin{array}{c}\mathrm{mlO} 2 / \\
\min \end{array}$ & $\begin{array}{l}\mathrm{mlO} 2 / \\
\mathrm{min} / \mathrm{kg}\end{array}$ & watt & Watt & watt/kg & watt $/ \mathrm{kg}$ \\
\hline U16DK & 11 & 194 & 80,1 & 1512 & 4494 & 56,2 & 968 & 711 & 12,2 & 8,90 \\
\hline U20DK & 16 & 192 & $92,5 \S$ & $1902 \S$ & $5416 \S$ & 58,7 & $1068 \S$ & $819 \S$ & 11,6 & 8,90 \\
\hline $\begin{array}{l}\text { 1.år- } \\
\text { Stenhus }\end{array}$ & 29 & $188 \S$ & $\begin{array}{c}81,5 \\
\# \S\end{array}$ & $1979 \S$ & $4818 \#$ & 59,2 & 1057 & 743 & $12,9 \#$ & 9,05 \\
\hline $\begin{array}{l}\text { Stenhus } \\
\text { 1. år }\end{array}$ & 11 & 188 & 81,8 & 1816 & 5167 & 62,8 & 987 & 727 & 12,1 & 8,88 \\
\hline $\begin{array}{l}\text { Stenhus } \\
\text { 3. år }\end{array}$ & 11 & 188 & $87,2^{*}$ & $2160^{*}$ & 5245 & 59,9 & $1152^{*}$ & $804^{*}$ & $13,2^{*}$ & 9,17 \\
\hline
\end{tabular}

Tabeltekst: Ungdomslandsholdene, U16DK og U20DK, blev testet i 2010, og stenhusspillerne er fra årgange 2010 til 2014 og blev testet i januar-februar måned i periode 2011-2015. I perioden blev 29 førsteårsspillere testet og 11 af disse er ligeledes blevet testet på deres tredje år i januar-februar måned (se nederste tabel). Markeringen § betyder statistisk signifikant forskel i forhold til U16, og \# er signifikant forskel i forhold til U20, mens * betyder signifikant forskel imellem 1. årstesten og 3. årstesten for de samme 11 stenhusspillere. Til den statistiske analyse blev der anvendt t-test og ANOVA tests. Signifikansniveauet var sat til $p<0,05$. YoYo IR1 står for YoYo interval restitutionstest niveau 1.

Når stenhusspillerne blev testet i januar eller februar måned, var det for at sikre, at de alle havde haft mindst et halvt år i talentudviklingsmiljøet. Dette var vigtigt, idet man ønskede at teste spillere, der havde vænnet sig til træningsmængden i stenhusprogrammet og dermed opnå data, der i mindre grad gav udtryk for den store, akutte forbedring, som man må forvente finder sted hos nyankomne stenhusspillere.

Ved sammenligning med landsholdene opfattes førsteårsmålingerne af sten- 
husspillerne som et udtryk for talentprogrammets udgangsniveau, mens forskellen fra disse til tredjeårsmålingerne er et udtryk for talentprogrammets løfteevne i løbet af de tre år - altså fraregnet den omtalte, markante, akutte udvikling.

Som det fremgår af tabellen er førsteårs-stenhusspillerne allerede efter seks måneder enten jævnbyrdige eller bedre end U16-spillerne. Stenhusspillernes gennemsnitshøjde er signifikant lavere end U16-landsholdets, men til gengæld vejer de mere. Stenhusspillerne leverede bedre løbepræstationer på YoYo-testen, og generelt set ligger de i den gode ende inden for alle måleparametre, om end de ikke er signifikant bedre end U16-spillerne.

Sammenligner man med U20-spillerne, er det kun den maksimale iltoptagelse og kropsvægten som er signifikant lavere hos stenhusspillerne. I resten af kategorierne er stenhusspillerne på niveau med U20-spillerne. Det skal bemærkes, at stenhusspillerne ligger højere på den vægtkorrigerede anaerobe effekt, og selvom dette delvist kan forklares med de cirka $10 \mathrm{~kg}$ tungere vægt hos U2O-spillerne, er det imponerende. Tidligere studier har nemlig vist, at den anaerobe effekt er den mest anvendelige parameter ved sammenligninger af træningsgrupper i modsætning til den anaerobe kapacitet, hvor man sjældent ser signifikante forskelle (Delextrat et al. 2008).

Skaber træningen i stenhusmiljøet fysisk udvikling? Svaret er JA. De løber markant længere på tredjeåret sammenlignet med førsteåret, og de forbedrer ligeledes deres absolutte og vægtkorrigerede anaerobe effekt samt den absolutte anaerobe kapacitet. Styrketræningsprogrammets effektivitet kommer til udtryk ved at spillerne markant forøger deres vægt, og ved almindelig observation af spillerne, tilskrives vægtforøgelsen primært en øget muskelmasse. Sammenligner man med tunesiske ungdomsholdsholdspillere, af tilsvarende alder, vægt og højde, har stenhusspillerne et markant højere kondital, dvs. 52,8 sammenlignet 59,9 mlO2/kg/ min (Abdelkrim et al., 2007).

Sammenfattende kan man sige, at det er tydeligt fra ovenstående datasæt, at stenhusspillernes træningsprogram sikrer den rigtige og nødvendige fysiske udvikling af basketballspillere i 15 til 18-års-alderen. Spillerne underpræsterer ikke på nogle af parametrene, men ligger på niveau med landets bedste udvalgte U16-spillere og endda, på nogle af parametrene, på niveau med U20-landsholdsspillerne.

Denne sammenligning er lavet på gruppe og holdniveau. Skulle man lave en mere positionsspecifik analyse, ville det kræve langt flere spillere. Alligevel kan man sige, at denne sammenligning tydeligt viser, hvilken gruppe af spillere, der er på Stenhus, og hvordan de udvikles som gruppe i det miljø af individuelle og kollektive sammenhænge som Stenhus Basketball College tilbyder spillerne. Der er som nævnt en række andre parametre, man med fordel kunne teste, eksempelvis indenfor det motoriske område, og sådanne tiltag er påbegyndt i samarbejde med forskere fra Københavns Universitet. 


\section{SAMMENFATNING}

Det er seks år siden Stenhus Basketball College blev oprettet. Vi har i denne artikel beskrevet en lang række af tankerne bag oprettelsen og udviklingen af dette talentudviklingsmiljø, der tilbyder et skarpt fokus på den tekniske, taktiske og fysiologiske udvikling af spillerne. Skolen er meget opmærksom på, at spillerne skal udfordres individuelt og kollektivt, hvilket kommer til udtryk igennem selektionen af spillere, og ved at spillerne deltager som et hold i U19-turneringen. Vi har også beskrevet, hvordan talentudviklingsmiljøet på Stenhus skaber gode muligheder for den menneskelige og boglige udvikling i kraft af den tætte sammenknytning mellem basketballtræningen og skolegangen, der bl.a. skyldes, at lærere og trænere ofte er de samme personer.

Basketball er et intermittent spil, der har en multikomponent arbejdskravsprofil. Der er mange intense aktioner (sprints, hop og sideversbevægelser), der er afbrudt af faser med lavere intensitet. Dette betyder derfor, at man skal kunne levere en høj anaerob og aerob energiomsætning, hvilket stenhusspillerne på tredje år med tydelighed kan, når man vurderer deres testresultater. Præstationsfremgangen på interval-restitutions-løbetesten, der er den mest spilnære test, er markant og tydelig fra 1. år til 3. år, og slutniveauet ligger væsentlig højere end U2O-ungdomslandsholdspillernes niveau. På den baggrund, må man konkludere, at det fysiske program på Stenhus Basketball College skaber den træningsfysiologiske udvikling, som er påkrævet for, at spillerne på bedste vis kan indgå på seniorniveau, når deres tid i talentmiljøet er forbi.

Stenhus Basketball College kan navnlig forbedre sig ved at rekruttere større og dygtigere spillere samt udvikle spillernes mentale styrke - et område som ikke er blevet bearbejdet i denne artikel. Desuden vil det være gavnligt for spillerne, såvel som for Stenhus Basketball College, hvis man kunne udvikle spilnære testbatterier, der kan informere om talenternes spilintelligens og motoriske evner. Dette ville være værdifuldt i forbindelse med at indkredse spillernes potentialer og derigennem forbedre udviklingen over de tre år på skolen.

På seks år har skolen udvidet sin kapacitet og favner mange andre idrætstalenter. Skolen arbejder til dagligt med 75 unge talenter indenfor badminton, fodbold, håndbold og tennis, som skaber en unik sportsprofil for skolen set i et dansk perspektiv. Igennem samme periode har skolen formået at udvikle en god og solid økonomisk model for talentmiljøet og skabt virkelig gode træningsfaciliteter. Træningsfacilliterne kan næppe forbedres yderligere, men at opretholde den sunde økonomi vil formentlig blive en udfordring, ligesom rekrutteringen af spillere og fastholdelsen af ressourcepersonerne i miljøet vil være vigtige opgaver i årene, der kommer. Disse tre forhold er meget væsentlige for, at miljøet kan bevare sin kvalitet, og dem skal der derfor konstant være udviklingsfokus på. 


\section{REFERENCER}

Abdelkrim BN, El Fazaa S, El Ati J. (2007). Time-motion analysis and physiological data of elite under-19-year-old basketball players during competition. Br J Sports Med., Feb; 41(2): 69-75.

Delextrat A, Cohen D. (2008). Physiological testing of basketball players: toward a standard evaluation of anaerobic fitness. J Strength Cond Res. Jul; 22(4): 1066-72.

Henriksen, Kristoffer (2011). Talentudviklingsmiljøer i verdensklasse. Dansk Psykologisk Forlag.

Team Danmark (2013). Værdisæt for talentudvikling i Danmark. TALENTHUSET. Hentet 1. december 2016 fra: http://www.teamdanmark.dk/-/media/Team\%2oDanmark/ Media\%20Archive/Documents/Forside/Udgivelser/Talentudvikling/TD\%20V\%c3\%a6rdis\%c3\%a6t\%2ofor\%2otalentudvikling\%202.pdf

d'Arripe-Longueville F, Gernigon C, Huet ML, Winnykamen F, Cadopi M (2002). Peer-Assisted Learning in the Physical Activity Domain: Dyad Type and Gender Differences, Journal of Sport and Exercise Psychology, September. 